\title{
HRST VZPOMÍNEK NA NOVODOBOU HISTORII UNIVERZITNÍHO ARCHIVU ANEB OD KAVKY PO LITSCHE
}

\author{
IVANA ČORNEJOVÁ
}

\section{SOME RECOLLECTIONS PERTAINING TO RECENT HISTORY OF THE UNIVERSITY ARCHIVE OR FROM KAVKA TO LITSCH}

These recollections by a long-term employee of the Archive of the Charles University offer reminiscences of various colleagues as well as the atmosphere of this institution, as it changed between the 1968, when the author started working there, until a new turning point, which came in 1989.

Keywords: Archive of the Charles University - memoirs - František Kavka - Karel Litsch

DOI: $10.14712 / 23365730.2018 .34$

Práh univerzitního archivu jsem poprvé překročila v pondělí 2. září 1968 jako nová „pomvědka“ a čerstvě zapsaná studentka prvního ročníku oboru archivnictví - dějepis na Filozofické fakultě Univerzity Karlovy. Vstup do budovy byl ohlašován zavěšeným zvonkem, jehož táhlo (ne nepřipomínající záchodové splachovadlo) viselo před vchodové dveře. Pomocným vědeckým silám byla vyhrazena malá místnost v prvním patře tehdy zcela zánovní budovy, kam se archiv přemístil z nevyhovujících sklepních prostor na Právnické fakultě. Uvítalo mne tam velmi přátelské prostředí, které tvořili jednak další studenti (ti mimopražští se ovšem dostavili až v říjnu), jednak vědečtí a odborní pracovníci $\mathrm{v}$ čele $\mathrm{s}$ tehdejším ředitelem profesorem Františkem Kavkou. K místním učeným pánům jsem vzhlížela s neskonalým obdivem. Ano, pánům, protože ta učená společnost byla ryze pánská, dvě dámy - paní Paziková a Šeráková - zastávaly místa knihovnice a sekretářky.

Vzhledem k tomu, že od srpnové okupace uplynulo jen několik dní, věda a odborná práce zůstaly zcela ve stínu aktuálních politických debat. V knihovnické pracovně se konaly debatní kroužky, kde diskusím kralovali zejména dva důstojní vousatí muži, Karel Kučera a Miroslav Truc, zahaleni do dýmu kvalitních viržinek (Kučera) a četných cigaret (Truc). Záhy jsem byla pověřena důležitou a zodpovědnou činností. Byl mi přidělen asi dvoulitrový demižon, s nímž jsem chodila do moravské vinárny Rakvická vícha v Kamzíkově ulici, odkud jsem debatující zásobovala kvalitním mokem. Ostatně rok 1968 neznamenal jen počátek národního úpadku, ale došlo i k rozvoji ne-státního podnikání (především družstevního) a v centru Starého Města pražského se objevilo množství vinárniček a hostinců, mj. i pro potěšení lidu studentského (kromě už zmíněné Víchy to byla Liška Bystrouška v Karlově ulici, vinárny U Golema a U Rudolfa v Maislovce nebo mezi umělci populární rekonstruovaná vinárna v Křižovnické ulici). 
Ústav pro dějiny University Karlovy, který byl zř́izen především díky aktivitě zmíněných pánů Kavky, Kučery a Truce, kteří měli dobré kontakty na rektorátu, zastiňoval do jisté míry s ním spojený archiv. Vedení ústavu přijal profesor František Kavka. ${ }^{5}$ Archivní práce měl na starosti doktor Josef Hanzal, jenž byl agilním činovníkem Historického klubu, který tehdy sice nezakazován, ale oficiálními místy nepodporován udržoval přednáškovou činnost a především kontakty s historiky, kteří se stali po roce 1948 nežádoucími. Dostala jsem na starost rozesílání pozvánek jeho členům. Díky klubovým přednáškám jsem v sedmdesátých letech mohla poznat i takové osobnosti, jako byli František Kutnar nebo Zdeněk Kalista. Dalším archivářem, který měl na starosti pomocné vědecké síly, byl Pavel Aixner, člověk poněkud složité povahy, jenž později vstoupil do kněžského semináře. Tehdy nejmladším členem kolektivu byl Zdeněk Pousta. Odborní a vědečtí pracovníci Ústavu pro dějiny University Karlovy ${ }^{6}$ byli nejen muži vážení, ale také rádně odměňovaní. Jejich platy dokonce převyšovaly tehdejši průměr $\mathrm{v}$ analogických institucích, takže byli ne tak dobře honorovanými kolegy zváni „milostpáni““?

Ostatně pokud se zadíváme okem kritickým na vědeckou produkci tohoto pracoviště ještě před rokem 1968, musíme si uvědomit, že její tvưrci se těšili př́zni naprosto právem. V šedesátých letech vznikla stěžejní díla, dodnes nepřekonané práce, z nichž těží řada badatelů. Kromě článků v časopise Historia Universitatis Carolinae Pragensis (který spatřil světlo světa také díky nim) jsou to především Stručné dějiny University Karlovy, první ucelené zpracování historie nejstaršího vysokého učení ve střední Evropě po Tomkově archaické knize. ${ }^{8}$ „Domácí“ autorský kolektiv byl rozšířen ještě o Františka Šmahela, který suverénně pojednal o husitském vysokém učení a humanismu. ${ }^{9}$ I s odstupem doby je nutno přiznat, že navzdory marxistické ideologii, projevující se zejména v pasážích o novějších dějinách, je to dílo bravurně stylizované a podává na malém prostoru (celkem 344 tiskových stran) nový komplexní pohled na osudy pražské univerzity. Vedle toho tehdy díky úsilí Karla Kučery a Miroslava Truce vznikl archivní průvodce ${ }^{10}$ (nikdy poté neinovovaný) a dvě precizní edice: nejstarší dochované lékařské matriky a matriky (alba) jezuitské akademie u sv. Klimenta. ${ }^{11}$ Všechny tyto publikace měly být vstupními svazky široce koncipovaných edičních řad, které však nebyly nikdy realizovány. Bohužel obdobně jako celá řada dalších projektů $\mathrm{v}$ univerzitním archivu...

Navzdory těžké době a událostem, které se odehrávaly př́mo v bezprostřední blízkosti sídla Ústavu a univerzitního archivu (pohřeb Jana Palacha v lednu 1969), plynul vnitřní život poklidně a bez větších turbulencí. Mezi pomvědy byli i dva pozdější zaměstnanci tohoto archivu: Michal Svatoš a Jindra Kubičcková (provdaná Duchoňová). Pomocné vědecké síly se nenásilným způsobem „zacvičovaly“ ve službě badatelům a jiné archivní činnosti, protože jim byla svěřena většina rešeršní agendy, připravování podkladů pro vystavování náhradních studijních dokladů a vyhledávání materiálů pro badatele. A pak tu bylo četné

\footnotetext{
5 Za upřesnění okolností spojených se vznikem Ústavu velice děkuji Zdeňku Poustovi.

6 Pod tímto názvem se samozřejmě skrýval i univerzitní archiv.

7 Lehce nadprůměrná výše mezd v naší instituci se udržela až do osmdesátých let minulého století.

8 Wáclav Wladivoj Tомек, Geschichte der Prager Universität, Prag 1849.

9 František Kavka (ed.), Stručné dějiny University Karlovy, Praha 1964. Spoluautory byli Jan Havránek, Karel Kučera, František Šmahel a Miroslav Truc.

10 Karel KučERA - Miroslav Truc, Archiv University Karlovy. Průvodce po archivnich fondech, Praha 1961.

11 Miroslav Truc (ed.), Album Academiae Pragensis Societatis Iesu 1573-1617 (1565-1624), Praha 1968; Karel KuČERA - Miroslav Truc (eds.), Matricula facultatis medicae Universitatis Pragensis 1657-1783, Praha 1968.
} 
stěhování materiálů $\mathrm{z}$ fakult atp. Archiv byl sice $\mathrm{z}$ budovy právnické fakulty už přemístěn (o přsun starých těžkých katalogů se při tehdejší neexistenci profesionálních firem postarali studenti z fakulty tělesné výchovy a sportu), ale přejímky z fakult neustávaly. A ačkoliv tehdy na rektorátě i fakultách existovaly četné sbory manuálních pracovníkủ (tzv. nádvorní čety apod.), stěhování „papírư“ jaksi nikdy nespadalo do jejich kompetence.

V roce 1970 byla idyla panující v Ústavu radikálně narušena zásahem StB, která vpadla do budovy hledajíc ,podvratné materiály“ tam údajně shromážděné, préedevším dokumenty svědčící o kontrarevoluci na univerzitě a památky z Palachova pohřbu. Bohužel se toto stalo vhodnou záminkou pro rozprášení zdejšího pracoviště. Svého místa byl zbaven profesor František Kavka, který musel odejít i z katedry českých a československých dějin na Filozofické fakultě Univerzity Karlovy, dále Miroslav Truc, Karel Kučera i Josef Hanzal a Zdeněk Pousta. Stejný osud potkal také obě administrativní pracovnice. Tím se skončila skvělá éra instituce, která si vydobyla velmi dobrou pověst doma i v zahraničí a nejen v oboru univerzitních dějin se nesmazatelně zapsala do moderní české historiografie. František Kavka nalezl nové místo v Židovském muzeu, sice klidné, ale nesrovnatelné s předešlým prestižním postavením, i když se mezi spolupracovníky těšil náležité úctě. Spolu s manželkou se rovněž museli vystěhovat z nádherného profesorského bytu v Široké ulici a přemístit na sídliště Pankrác. Miroslav Truc zakotvil v Památníku národního písemnictví, Karel Kučera se uchýlil pod ochranu právního historika (a prověřeného soudruha) profesora Václava Vaněčka do dokumentačního oddělení Právnické fakulty Univerzity Karlovy, Josef Hanzal se ocitl v kabinetu Zdeňka Nejedlého, součásti Ústavu pro českou a světovou literaturu ČSAV, a jediný Zdeněk Pousta zůstal ve svazku univerzitního rektorátu (pod který Ústav pro dějiny UK i tehdy spadal), ovšem jako řidič. Ústav pro dějiny UK byl zrušen jako vědecké pracoviště a zbyl jenom archiv, $\mathrm{v}$ jehož rámci se vědecká práce na původní úrovni nepředpokládala. Ze starých zaměstnanců zbyli na místě pouze Josef Tříška, klasický filolog, výborný latinář, ale poněkud problematický člověk, a Jan Havránek, který zde byl dříve jen externistou. Jan Havránek se stal také novým pověreným vedoucím archivu.

Po dostudování byli na místa archivářů přijati Michal Svatoš a Jindra Duchoňová, kteří, jak už jsem naznačila, měli i náležitou praxi. Knihovnicí se stala Miloslava Kubová (provdaná Melanová), žačka profesora Kavky, která měla k univerzitním dějinám blízko: tématem její diplomové (posléze i rigorózní) práce byly univerzity založené Karlem IV. Knihovní administrativu obstarávala důchodkyně paní Kavanová, dokumentaci dostala na starost Miluše Toušková (provdaná Havránková, ale s vedoucím archivu ji spojovala jen shoda jmen). Jejího otce znali všichni mužští absolventi filozofické fakulty, protože tam byl vedoucím vojenské katedry. Sekretářkou se stala paní/soudružka Zahnašová, dáma ne zcela bystrého ducha, ale pro normalizační dobu vhodného rodinného zázemí, nebot' její manžel byl důstojníkem StB. Tím však nechci naznačit, že by se jejím prostřednictvím archiv dostal pod kontrolu této „tajné“ organizace. Pravděpodobně ne, protože soudruh Zahnaš měl o inteligenci své ženy asi ještě nižší mínění než její spolupracovníci. V roce 1972 odešla Miluše Havránková na mateřskou dovolenou a já jsem dostala ještě před ukončením studia možnost pracovat $\mathrm{v}$ univerzitním archivu na poloviční úvazek, po absolutoriu potom na plný.

V roce 1974 skončila krátká etapa Havránkova vedení. Jako člověk vyškrtnutý z KSČ nebyl podle normalizačních zákonitostí způsobilým $\mathrm{k}$ řízení čehokoliv a na vedoucí místo v archivu nastoupila reaktivovaná spolehlivá soudružka docentka Marie Pravdová. Pro 
všechny to byl docela šok. Ačkoliv jsme už byli zvyklí na leccos, přece jenom většina věcí šla tak trochu okolo nás. Paní Pravdová vystudovala před válkou dějepis - zeměpis a češtinu na filozofické fakultě, byla středoškolskou profesorkou a nějaký čas působila i na Pedagogické fakultě Univerzity Karlovy. Do ř́zení archivu se pustila energicky a vehementně, asi to i myslela dobře. Jenomže měla pod sebou a hlavně proti sobě kolektiv lidí mnohem mladších. V polovině sedmdesátých let přišel do archivu ještě Ondřej Polišenský, dočasně zde pracovala i Lud’a Klusáková (do té doby, než mohla nastoupit na katedru obecných dějin, kde jejímu působení bránila osobní nepřízeň profesora Oldřicha Říhy). K osazenstvu přibyly ještě dvě pracovnice $\mathrm{z}$ tehdejší fakulty osvěty a novinářství Eda Kriseová ${ }^{12} \mathrm{a}$ Zdena Šebková, jejichž pracoviště byla v průběhu mateřské dovolené zrušena. Naplnilo se tak nepsané pravidlo: kam s ,nepotřebnými“ lidmi - do archivu.

Do řad oponentů paní Pravdové, nebo, jak jsme jí tehdy ošklivě a zcela nekorektně ř́kali, „báby“, se velice aktivně zapojila rektorátní fotografka Marie Hlušičková, půvabná žena, která měla svou fotografickou laboratoř v př́zemí archivu. Nehodlám vydávat odpor většiny (ale rozhodně ne všech) tehdejších zaměstnanců archivu za projevy jakéhosi odboje, ale faktem je, že docentka Pravdová záhy zjistila, že s námi mnoho nezmůže. Na pravidelných pracovních poradách to vypadalo jak na „perském trhu“, paní vedoucí toho mnoho neprošlo. Ze zpětného pohledu musím přiznat, že místy neměla tak špatné nápady. Mezi ně patřil třeba soupis pramenů $\mathrm{k}$ dějinám školství v českých a moravských archivech - tedy bohužel opět nedokončený. Stejně tak nedokončená zůstala prríprava komplexního životopisného slovníku, který měl zahrnout celou dobu existence univerzity. Karty, na které se shromažd’ovaly bio-bibliografické údaje, se z části postupem doby poztrácely. Po pravdě řečeno, Marie Pravdová, ač kovaná komunistka, nikoho přímo nenutila ke vstupu do partaje či jiných podobných organizací, ani k účasti na jinde bezmála obligatorním VUMLu (Večerní univerzita marxismu-leninismu). Založením SSM na rektorátě byla tehdy stranickou organizací pověřena Lud’a Klusáková. Dokonce ani v roce 1977 paní Pravdová nevyzývala $\mathrm{k}$ podpisu anticharty.

I v sedmdesátých letech navštěvovali univerzitní archiv zahraniční badatelé. Zejména dva z nich, věkově blízcí tehdejším odborným zaměstnancům, se postupem doby stali našimi přáteli. Byli to Karen J. Freeze a Gary B. Cohen. ${ }^{13}$ Gary Cohen často vzpomíná, jak nám paní Pravdová zakazovala se s ním bavit nad rámec pracovních povinností a jak se ho sama snažila přesvědčovat o krásách socialistického zřizení. Oba zmínění badatelé, zabývající se přelomem 19. a 20. století, byli totiž vyslanci té „nejhorši“ “imperialistické země - USA. Odpor proti Garymu byl zjevně u paní Pravdové a její sekretářky Zahnašové motivován i primitivním antisemitismem.

V roce 1975 postihla archiv velmi nepř́ijemná povinnost, která se dotkla také mne osobně. ${ }^{14}$ Byla to přejímka písemné pozůstalosti rušené Univerzity 17 . listopadu. Tato vysoká

12 Eda Kriseová, která se spolu se Z. Šebkovou stala zaměstnankyní archivu na podkladě nezpochybnitelného práva zaměstnat ženy po návratu z mateřské dovolené i po zániku konkrétního pracoviš̌ě, posléze odešla sama „,do domácnosti“" s odůvodněním, že se chce věnovat literární činnosti.

13 Gary Cohen napsal vzpomínkový článek, v němž se zmiňuje i o svých studiích v AUK a šiřeji se zabývá svou perzekucí ze strany Státní bezpečnosti. Gary CoHen, Learning to deal with a Communist National Security State: Memories of an American Historian about Czechoslovakia in the 1970s and early 1980s, v tisku.

14 Snažily jsme se spolu s bývalou zaměstnankyní Univerzity 17. listopadu Sylvou Ostrovskou, žačkou a obdivovatelkou profesora Josefa Polišenského, zachránit z likvidovaných papírů, co se dalo. Kdyby nebylo především jejího úsilí, většina písemností by vzala za své. Makulaturu jsme likvidovaly spolu s tehdejšími pomvědy 
škola vznikla z politické motivace - po vzoru sovětské Univerzity Patrice Lumumby na pomoc studentům z ,rozvojových“ států. Těmi rozvojovými státy se tehdy myslely země Asie a Afriky, jejichž mladí lidé měli být indoktrinováni naším komunistickým režimem. Univerzita 17. listopadu byla založena z politické vůle a jiným politickým rozhodnutím byla poté zrušena (dodnes myslím není zřejmá pravá příčina likvidace). Do univerzitního archivu přešly písemnosti vztahující se ke studiu a studentům, zbytek převzal tehdejší Státní ústřední archiv. Rozhodnutí o tom, že studentika mají být součástí univerzitního archivu, bylo od počátku velmi pochybné: zrušená písemná pozůstalost státní instituce měla přejít automaticky do státního archivu. Tento fond znamenal značné zatížení agendy univerzitního archivu, protože žádosti o potvrzení studia i těch vyloučených (kterých bylo značné množství) byly přečetné.

Éra Marie Pravdové netrvala tak dlouho. V roce 1978 byla ve vedení archivu vystřídána právním historikem docentem Karlem Litschem. Během jejího působení dostal publikační př́ležitosti především Josef Třriška, už zmíněný filolog, který chrlil jednu podivnou knihu za druhou. ${ }^{15}$ Naznačila jsem, že se Marie Pravdová skutečně snažila o archiv a univerzitní památky starat - jedním z výsledků této péče bylo faksimile nejstarší univerzitní matriky, děkanské knihy artistické fakulty, jejíž originál je od roku 1945 nezvěstný. Faksimile bylo vydáno ve spolupráci s doktorem Karlem Beránkem se značnými finančními náklady z dochovaných fotodesek, ale bez veškerého kritického aparátu a v tiskové kvalitě, která je $\mathrm{z}$ dnešního pohledu absolutně nevyhovující. $Z$ tohoto důvodu jsou prŕíslušné výtisky dosud „výbavou“ archivních skladišt'. Vlastně ani nevím, proč paní Pravdová v roce 1978 odešla, zda na vlastní žádost, nebo zásahem ,shora“. Byla to v podstatě nešt’astná, osamělá bytost, které jedinou společnost dělalo několik koček, pro něž pravidelně nakupovala tehdy nedostatkové kvalitní hovězí maso.

Karel Litsch byl na vedoucí pozici vybrán rovněž jako prověřený soudruh. Ovšem ve srovnání s Marií Pravdovou to byl nebetyčný rozdíl. Litsch byl bytostně levicově orientovaný, jednak vlastním přesvědčením, jednak kvůli rodinným kořenům. Poté, co v Německu zemřeli oba jeho rodiče, byl vychováván v Čechách svým strýcem Robertem Brokem, známým dirigentem Osvobozeného a Národního divadla. Láska k hudbě a hudebnímu divadlu byla vlastní i Karlu Litschovi, který byl - v mládí sám člen pěveckého sboru - milovník opery a zejména hudby Richarda Wagnera. Karel Litsch byl ale především úžasný člověk, jenž měl pochopení pro mnoho lidských slabostí (pokud ovšem neškodily někomu jinému nebo nebyly výrazem lenosti a neplnění povinností). Za doby jeho vedení od roku 1978 do roku 1989 zavládla v univerzitním archivu neuvěřitelná pohoda, dokázal vždy přispět pomocí a poradit. Oplýval přirozenou autoritou, takže neměl problémy s tím, že by podřízení neplnili své úkoly (i když i takoví se našli). Přesto však možná mohl být někdy vůči svým podřízeným přísnější. V osmdesátých letech se osazenstvo archivu rozrostlo - přišla Blanka Nořížová (provdaná Zilynská), již k práci v univerzitním archivu oprávnilo téma diplomové práce - husitské synody. A dalším novým pracovníkem byl Miroslav Kunštát. Po emigraci fotografky Marie Hlušičkové do Německa, respektive Bavorska, nastoupila na

Jiřím Peškem a Zdeňkem Hojdou, z budovy na Gorkého (Senovážném) náměstí se vozila na ručním vozíku do nedaleké sběrny.

15 Pokud píši podivnou, vypadá to, jako bych apriorně chtěla podceňovat autorovu erudici. Jeho znalosti latiny byly skutečně vynikající, byl schopen i aktivní komunikace v tomto klasickém jazyce, ale jeho publikace jsou jen snůškami disparátních informací, i když je třeba je vždy pro úplnost citovat. 
její místo usměvavá a chichotavá Nad’a Jirásková. ${ }^{16}$ Archivní pohoda byla dovršena i změnou na místě sekretářky, když po paní Zahnašové nastoupila Blanka Šachová, která výborně zapadla do kolektivu. V knihovně pracovaly Marie Štemberková a Jiřina Urbanová, někdejší zaměstnankyně bibliotéky Ústavu českých a světových dějin ČSAV. Tedy pokud hovořím o pohodovém kolektivu, je třeba přiznat, že čas pracovní byl střídán zábavou a posezení u vína nebyla na pracovišti rozhodně ř́́dkým jevem. Blanka Šachová také s naprostým přehledem zvládala nejen agendu archivu, ale i vedení univerzitních matrik, které připadlo (nepatřičně) univerzitnímu archivu ještě za Marie Pravdové a zdejším pracovníkům přidalo $\mathrm{k}$ běžnému stěhování písemností $\mathrm{z}$ fakult a rektorátu i pravidelné přenášení tubusů na okázalé univerzitní diplomy.

$\mathrm{V}$ předchozím textu jsem připomněla některé pomocné vědecké síly. Bylo jich v průběhu onoho dvacetiletí před rokem 1989 samozřejmě mnohem víc a řada $\mathrm{z}$ nich se později výrazně zapsala do dějin naší historiografie a vysokoškolské výuky. Aniž bych si zde činila nárok na úplnost, uvedu jména alespoň některých (vynasnažím se přitom postupovat v chronologickém pořadí od doby nejstarší): Jiří Pešek a Zdeněk Hojda, archiváři a historici, po roce 1989 významní vysokoškolští učitelé, Jan Hozák, dlouholetý archivář Národního technického muzea, Jitka Lněničková, znalkyně sklářské historie, Nad’a Štěpinová (provdaná Kubů), kastelánka na Karlštejně, Dana Vajgendová (provdaná Picková), vyučující na katedře obecných dějin Filozofické fakulty Univerzity Karlovy, Jan Županič, nyní profesor historie Filozofické fakulty Univerzity Karlovy, Alice Klášterská (provdaná Velková), odbornice na dějiny venkova a vysokoškolská pedagožka, Jiří Pokorný, archivář a posléze i vysokoškolský učitel, Jan Hrdina, medievista, Eva Doležalová, rovněž medievistka a v současné době zástupkyně ředitele Historického ústavu AV ČR, nebo Eva Tichá, lingvistka, a řada dalších. Tedy po pravdě řečeno, ne že by naši pomvědi odvedli úžasné pořádací práce, přečasto byli zaměstnáni různým stěhováním, ale hlavně, snad ke svému dobru, získali v archivu dobrý vztah $\mathrm{k}$ historické práci.

Archiv Univerzity Karlovy i v dobách, kdy nebyl vědeckým pracovištěm, byl místem setkávání. Setkávání různých odborníků domácích i zahraničních. Před rokem 1989 nebylo tolik badatelů jako nyní, ale o to více se jednalo o zajímavější osobnosti. Neměli jsme samostatného pracovníka na službu v badatelně, ale pravidelně jsme se na tomto místě všichni stř́dali. Přiznávám, že mi služba v badatelně vůbec nevadila, ba naopak. Badatelů bylo sice méně, ale jednalo se o odborníky a odbornice, od nichž člověk mohl načerpat mnohé poučení. Mezi ty nejčastější patřil Karel Beránek, jenž byl kdysi, na sklonku čtyřicátých let 20. století, sám pomvědem a stále znal staré fondy našeho archivu lépe než my, stávající zaměstnanci, či Pavel Křrivský, který mne v dobách, kdy př́ślušná literatura byla jen těžko dostupná, zasvětil do církevních dějin a s nímž jsem vedla dlouhé debaty, které pro mne byly velkým obohacením, stejně tak jako diskuse s jeho životní družkou Marií Pavlíkovou. Zajímavé byly i rozhovory s literárním historikem Jaroslavem Kolárem nebo se Zdeňkem Horským, historikem, fyzikem, filozofem, teoretickým i praktickým muzikantem, prostě bez nadsázky renesančním člověkem. A to připomínám jen ty, kteří badatelnu navštěvovali pravidelně. Občas zavítal také František Šmahel, který se po svém vyhození z Ústavu

16 V textu nezmiňuji zdaleka všechny, kteří se na krátký čas v archivu zastavili. Připomenu zde alespoň Ivanu Bernáškovou, pozdější archivářku řady významných institucí, nebo Tomáše Hokůva, jenž své psychické problémy bohužel vyřešil sebevraždou. Nad’a Jirásková se nakonec $\mathrm{v}$ druhé polovině osmdesátých let provdala do Německa a rektorátním fotografem se stal mnohem méně veselý Jan Smit. 
československých dějin stal řidičem pražské tramvaje (!!!), než mohl zakotvit v táborském Muzeu husitského revolučního hnutí. Společenským centrem byla také fotolaboratoř, kam za půvabnou fotografkou docházeli mnozí mužové známí v uměleckém světě (napríklad sochař Hugo Demartini, fotograf a výtvarník Jaroslav Franta, řečený Ferson, architekt Vladimír Šlapeta - bratr kameramana Ivana) a také její kamarádka Blanka Zemanová, první manželka našeho současného prezidenta.

Na dobu předlistopadovou byl univerzitní archiv také neskutečným místem setkávání mezinárodního. S jistou nadsázkou mohu ř́ci, že nám sice byl svět (ten „západni'“) vesměs uzavřen, ale tento svět, anebo alespoň jeho část, přicházela za námi. Opět se omlouvám, protože se obávám, že zdaleka neuvedu všechny, koho jsme v archivu mohli přivítat. O Karen Freeze a Garym Cohenovi už byla řeč - Gary nakonec v osmdesátých letech přestal do republiky vůbec jezdit po traumatickém zážitku výslechu na StB v Bartolomějské ulici a Karen přicházela už jen jako př́telkyně, protože se věnovala jiným tématům, dějinám designu aj. Předtím za ní do archivu často docházel i její tehdejší manžel Gregory, významný rusista z Brandeis University v Bostonu. Univerzitní archiv často vítal také francouzskou bohemistku Marii-Elizabeth Ducreux, která nám (kromě vřelého přátelství) zajišt'ovala předplatné časopisu Annales. Nejvíce zahraničních návštěvníků přijímal Jan Havránek, jenž byl oblíbený i cizími studenty, jimž dokázal předestř́t s nadhledem a vtipem sobě vlastním české dějiny tak, jako nikdo jiný. Jeho přáteli byli vynikající historikové manželé Iggersovi, navštívil ho také kanadský dějepisec Gordon Skilling a četní badatelé z Rakouska, Polska či Bulharska a jiných slovanských států. Pochopitelně jsme měli badatele a kolegy z „tábora socialismu“. Pravidelně a ráda jezdila do Prahy sovětská husitoložka profesorka Laptěva, jež se v našem městě většinou věnovala nakupování, a jako průvodkyně jí byla přidělena Marie Štemberková. Naším přítelem se stal i její žák Alexander (Saša) Randin, který nakonec v Československu zakotvil a nyní působí na bratislavské univerzitě. Zapomenout nesmím ani na polského historika věnujícího se Pražskému povstání, v devadesátých letech polského velvyslance v České republice, Andrzeje Krawczyka. Za jiné rakouské badatele zmíním vídeňského archiváře Hanse Georga Plaschku, který byl, pln upř́ímného nadšení, jedním z prvních našich hostů po listopadu 1989, stejně jako další Vídeňák, historik a filmový historik Gernot Heiss. Německý kolega Ralph Melville dokázal v osmdesátých letech zajistit pro české zájemce několikaměsiční studijní pobyty v Mohuči.

Zajímavými známými se mohli pochlubit i dva zaměstnanci univerzitního archivu, kteří byli zbaveni možnosti vyučovat na filozofické fakultě a odsunuti (kam jinam, opět) do archivu. Filozof Ivo Tretera, kromě jiného prítel Bohumila Hrabala, se záhy stal výborným kamarádem. Profesor Theodor Syllaba zahlcoval (i nedobrovolné) posluchače přečetnými informacemi o objektu svého studijního zájmu Janu Gebauerovi, za což si vysloužil (inu poněkud plytkou) přezdívku Gebouš. Z šedesátých let, kdy Syllaba patřil k typickým intelektuálům té doby, pocházelo jeho přátelství s hvězdou německé filozofie a sociologie Jürgenem Habermasem. I jeho (spolu s manželkou) jsme mohli v našem archivu několikrát potkat.

Př́jiemnou atmosféru v archivu př́liš nenarušily ani soukromé spory mezi dvěma kolegyněmi. Archiv postihly i velmi smutné události - dvě předčasná úmrtí kolegů. Jindra Duchoňová zemřela v roce 1988 po fatálním onemocnění rakovinou a Tomáš Hokův, jenž byl krátký čas naším spolupracovníkem, spáchal sebevraždu. Nedlouho po listopadu 1989 a poté, co dovršil šedesát let života, prohlásil docent Litsch sama sebe za „starou strukturu“ 
a odešel do důchodu. Všichni, kdo zažili jeho šéfování, jistě nikdy nezapomenou na ta př́ijemná a pohodová léta. Karel Litsch patřil k nemnoha lidem, pro které není funkce vedoucího prostředkem k často (hypotetickému) zvýšení prestiže a posílení vlastního ega, ale oplýval přirozeným talentem vytvářet kolem sebe př́ijemnou atmosféru. ${ }^{17}$

\section{IVANA ČORNEJOVÁ}

\section{Eine Handvoll Erinnerungen an die jüngste Geschichte des Universitätsarchivs oder: von Kavka bis zu Litsch}

\section{ZUSAMMENFASSUNG}

In dieser Skizze erinnert die langjährige Mitarbeiterin des Universitätsarchivs an Kollegen und Kolleginnen dieser Einrichtung sowie an die dort herrschende Atmosphäre, wie diese sich von 1968 an, als Verfasserin ihre Stelle im Universitätsarchiv antrat, bis zu einer erneuten Wende im Jahre 1989 veränderte. František Kavka tritt als erster Direktor des in den 1960er Jahren gegründeten Instituts für die Geschichte der Karlsuniversität auf; er deckte zeitweilig die Archivarbeit sowie die Forschungstätigkeit dieser Institution ab. Nach der großen Säuberung im Rahmen der sog. Normalisierung 1970 und einer kurzen Zeit, in welcher Jan Havránek das Archiv leitete, übernahm Marie Pravdová als neue Direktorin die Leitung des Archivs. Mit ihrem Amtsantritt verschlechterten sich die Verhältnisse in dieser Institution nachhaltig. Demgegenüber verwandelte K. Litsch, der als neuer Direktor 1978 sein Amt antrat, diese Arbeitsstätte in eine Oase freundschaftlicher Beziehungen und fruchtbarer Forschungsarbeit. Verfasserin lässt eine ganze Reihe Namen von Mitarbeitern, wissenschaftlichen Hilfskräften und ausländischen Gästen vorüberziehen, die dieser Institution den Glanz einer Stätte nützlicher Zusammenarbeit inmitten einer damals grauen Realität verliehen.

Deutsche Übersetzung Wolf B. Oerter

Ivana Čornejová

Ústav dějin a archiv UK, Praha

Ivana.Cornejova@seznam.cz

17 Za přečtení textu a připomínky děkuji Blance Šachové, Zdeňku Poustovi a Garymu Cohenovi. 